\title{
Kontribusi Pendapatan Usahatani Jeruk Siam terhadap Pendapatan Rumah Tangga Petani di Desa Tegalsari, Kecamatan Tegalsari, Kabupaten Banyuwangi
}

\author{
RIA FLORA JANUWA PUTRI,I DEWA GEDE AGUNG, \\ PUTU UDAYANI WIJAYANTI
}

\author{
Program Studi Agribisnis Fakultas Pertanian Universitas Udayana \\ Jalan PB Sudirman 80232 Bali \\ Email : riaflora19@gmail.com \\ dewagedeagung@unud.ac.id
}

\begin{abstract}
Contribution of Tangerine Farming Revenue in Relation with the Total Household Income of Farmers in the Tegalsari Village, Tegalsari District, Banyuwangi Regency.
\end{abstract}

Tangerine, or also known as jeruk keprok in Bahasa, is one of the many species of citrus fruit which has been widely cultivated in various regions in Indonesia. Although its market fluctuate from time to time, but the public interest in tangerine never disappeared.This study aims to determine the contribution of tangerine farming revenue in relation with the total household income of the farmers in the Komojoyo Farmer Group. The results of this research obtained that the average tangerine farming revenue

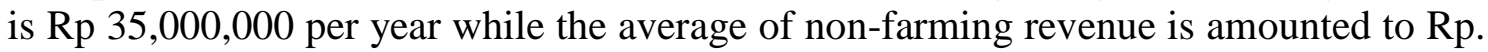
$8,761,304$ per year. It proved that citrus farm revenue is greater than non-farm revenue. There are constraints faced by Komojoyo Farmer Group, namely, the aphid pest, the lack of guidance from agricultural counselor, and sales methods are still using the services of middlemen. It can be evidenced from the percentages obtained: the pest was $11 \%$, guidance from agricultural counselor at $65 \%$, and sales of middlemen by $24 \%$. From these percentages, it can be seen that the biggest obstacle faced by Komojoyo farmer group is the lack of guidance from agricultural counselor. .

.Keywords: citrus, farming revenue, non-farm revenue

\section{Pendahuluan}

\subsection{Latar Belakang}

Indonesia merupakan negara agraris, dimana sektor pertanian dalam tatanan pembangunan nasional memegang peranan penting dalam menyediakan pangan bagi seluruh penduduk. Sektor pertanian juga merupakan sektor andalan sebagai penyumbang devisa negara, termasuk pertanian di bidang usahatani jeruk. Pembangunan pertanian merupakan bagian dari pembangunan ekonomi dan masyarakat secara umum. Pembangunan pertanian memberikan sumbangan kepada masyarakat 
serta menjamin bahwa pembangunan yang menyeluruh itu mencakup penduduk yang hidup dan bertani, yang jumlahnya besar dan untuk tahun-tahun mendatang (Krisnandhi, 2009). Tanaman jeruk adalah tanaman buah tahunan yang berasal dari Asia. Cina dipercaya sebagai tempat pertama kali jeruk tumbuh. Sejak ratusan tahun yang lalu, jeruk sudah tumbuh di Indonesia dengan baik secara alami atau dibudidayakan. Tanaman jeruk yang ada di Indonesia adalah peninggalan orang Belanda yang mendatangkan jeruk manis dan keprok dari Amerika dan Italia (Deptan, 2012).

Peranan jeruk sebagai tanaman hortikultura, makin hari makin terasa penting bagi petani, karena nilai ekonomisnya yang tinggi. Buah ini enak rasanya, dan merupakan bahan pelengkap utama dalam menunjang gizi keluarga sehari-hari. Buah jeruk yang rasanya menyegarkan banyak mengandung vitamin $\mathrm{C}$ dan $\mathrm{A}$ dalam jumlah yang cukup banyak (Sarwono, 1986). Sektor pertanian di Kabupaten Banyuwangi terdapat pengembangan dalam bidang holtikultura pada tahun 2014. Ada delapan kecamatan di Banyuwangi yang menjadi sentra jeruk. Salah satunya Kecamatan Tegalsari, Desa Tegalsari. Produksi jeruk siam pada tahun 2011, luas panen jeruk siam di Kabupaten Banyuwangi 10.726,70 ha, dan pada tahun 2012, 8.171,20 ha (Dinas Pertanian, Kehutanan, dan Perkebunan Kabupaten Banyuwangi, 2012). Berdasarkan data yang diperoleh, terjadi peningkatan hasil panen tanaman jeruk meskipun luas panen menyusut. Tahun 2011 luas panen di Desa Tegalsari seluas 10.726,70 ha dan tahun 2012 mengalami penyusutan menjadi 8.171,20 ha. Produktivitas hasil jeruk tahun 2011 hanya mencapai 172,07 kuintal per hektar. Pada tahun 2012, rata-rata mencapai 202,12 kuintal per hektar. (Dinas Pertanian, Kehutanan, dan Perkebunan Kabupaten Banyuwangi, 2012). Petani tidak hanya mengandalkan usahatani jeruk untuk dapat menopang hidup mereka, ada pula petani yang menambah pendapatannya dari luar sektor pertanian seperti pegawai swasta, kuli bangunan, berdagang, dan sebagainya. Adanya data tersebut, maka dilakukan penelitian tentang kontribusi usahatani jeruk siam terhadap total pendapatan rumah tangga petani di Desa Tegalsari, Kecamatan Tegalsari, Kabupaten Banyuwangi.

\subsection{Rumusan Masalah}

Berdasarkan latar belakang yang telah dipaparkan di atas, dapat dirumuskan suatu masalah, beberapa permasalahan sebagai berikut :

1. Berapakah kontribusi pendapatan usahatani jeruk siam terhadap total pendapatan rumah tangga petani di Desa Tegalsari, Kecamatan Tegalsari, Kabupaten Banyuwangi.

2. Apakah kendala-kendala yang dihadapi petani dalam usahatani jeruk siam di Desa Tegalsari, Kecamatan Tegalsari, Kabupaten Banyuwangi.

\subsection{Tujuan Penelitian}

Berdasarkan perumusan masalah yang telah di uraikan, maka tujuan dari penelitian ini adalah untuk : 
1. Mengetahui kontribusi pendapatan usahatani jeruk siam terhadap total pendapatan rumah tangga petani di Desa Tegalsari, Kecamatan Tegalsari, Kabupaten Banyuwangi.

2. Mengetahui kendala-kendala yang dihadapi petani dalam usahatani jeruk siam di Desa Tegalsari, Kecamatan Tegalsari, Kabupaten Banyuwangi.

\section{Metode Penelitian}

\subsection{Lokasi dan Waktu Penelitian}

Penelitian ini dilaksanakan pada Kelompok Tani Komojoyo, di Desa Tegalsari, Kecamatan Tegalsari, Kabupaten Banyuwangi. Waktu penelitian dimulai pada bulan Februari hingga Juni 2015. Lokasi penelitian dipilih secara sengaja (purposive sampling), dengan pertimbangan Desa Tegalsari merupakan salah satu dari delapan desa yang memasok jeruk siam untuk kawasan Kabupaten Banyuwangi dan luar kota lainnya di Indonesia.

\subsection{Populasi, Sampel, dan Variabel}

Menurut Mantra dan Kasto (1989), populasi adalah jumlah keseluruhan dari unit analisa yang ciri-cirinya akan diduga. Populasi dalam penelitian ini berjumlah 46 orang dan pengambilan sampel didalam penelitian ini diambil dengan metode sensus, sebanyak 46 orang yang diambil dari anggota Kelompok Tani Komojoyo Desa Tegalsari, Kecamatan Tegalsari, Kabupaten Banyuwangi. Variabel diartikan sebagai salah sesuatu yang akan menjadi objek pengamatan penelitian yang memiliki nilai bervariasi. Adapun variabel yang digunakan dalam penelitian ini adalah struktur biaya usahatani, penerimaan usahatani, variabel pendapatan usahatani, dan kendala-kendala usahatani jeruk siam.

\subsection{Metode Analisis Data}

Analisis data bertujuan untuk menyederhanakan data dalam bentuk yang lebih mudah dibaca dan diinterprestasikan secara rasional terhadap fakta-fakta yang ada di lapangan (Effendi dan Chris Manning, 1989). Data yang bersifat kuantitatif dianalisis dengan menggunakan metode analisis usahatani dan data yang bersifat kualitatif dianalisis dengan metode deskriptif. Analisis deskriptif yaitu suatu metode penyajian melalui penafsiran data yang ada dengan tujuan mendeskripsikan secara rinci suatu fenomena sosial tertentu dengan penafsiran disertai intepretasi rasional terhadap faktorfaktor yang terdapat di lapangan.

Rumus menghitung pendapatan rumah tangga petani jeruk siam dari usahatani dengan menggunakan rumus sebagai berikut :

$$
\mathrm{Y}_{\mathrm{ka}}=\mathrm{Y}_{\mathrm{d}}+\mathrm{D}
$$

Keterangan :

$\mathrm{Y}_{\mathrm{ka}}=$ Pendapatan rumah tangga

$\mathrm{Y}_{\mathrm{d}}=$ Pendapatan bersih usahatani

$\mathrm{D}=$ Total biaya variabel bukan tunai 
Sumber pendapatan dari sektor non pertanian dibedakan menjadi pendapatan dari industri rumah tangga, perdagangan, pegawai, jasa, buruh non pertanian, serta buruh subsektor pertanian lainnya (Sajogyo, 1990). Rumus mengetahui pendapatan total rumah tangga petani resonden menggunakan rumus :

$$
\mathrm{Y}_{\mathrm{t}}=\mathrm{Y}_{\mathrm{ka}}+\mathrm{Y}_{\mathrm{np}}
$$

Keterangan :

$\mathrm{Y}_{\mathrm{t}}=$ Pendapatan total

$\mathrm{Y}_{\mathrm{ka}}=$ Pendapatan rumah tangga

$\mathrm{Y}_{\mathrm{np}}=$ Pendapatan dari sektor non pertanian

Terdapat kriteria untuk mengetahui hasil kontribusi pendapatan usahatani jeruk siam terhadap total pendapatan rumah tangga petani. Maka dari itu, dibuatkan kriteria untuk menentukan seberapa besar hasil yang diperoleh, yang nantinya hasil kontribusi tersebut dapat dimasukkan kedalam kriteria yang telah dibuat.

Tabel 1.

Kriteria untuk mengukur Hasil Kontribusi Pendapatan Usahatani Jeruk Siam terhadap Total Pendapatan Rumah Tangga Petani di Desa Tegalsari, Kecamatan Tegalsari, Kabupaten Banyuwangi

\begin{tabular}{cccl}
\hline \multirow{2}{*}{ Kelas } & \multicolumn{2}{c}{ Batas kelas $(\%)$} & \multicolumn{1}{|}{ Kriteria } \\
\cline { 2 - 3 } & Bawah & Atas & Sangat rendah \\
\hline 1 & 0 & 20 & Rendah \\
2 & 20 & 40 & Sedang \\
3 & 40 & 60 & Tinggi \\
4 & 60 & 80 & Sangat tinggi \\
5 & 80 & 100 & \\
\hline
\end{tabular}

Berdasarkan ketentuan tersebut bahwa kriteria ini memiliki batas kelas 0 hingga 100 dengan kriteria sangat rendah hingga sangat tinggi, yang mana nantinya batas kelas tersebut menjadi acuan terhadap hasil kontribusi pendapatan yang telah dihitung menggunakan rumus kontribusi.

\section{Hasil dan Pembahasan}

\subsection{Biaya Produksi Jeruk Siam}

Biaya dalam usahatani biasanya diklasifikasikan menjadi dua, yaitu biaya tetap (fixed cost) dan biaya tidak tetap (variable cost). Biaya tetap umumnya jumlahnya relatif, dan terus dikeluarkan walaupun produksi yang diperoleh banyak atau sedikit. Contoh biaya tetap antara lain: sewa tanah, pajak, alat pertanian, dan iuran irigasi (Soekartawi, 1995). Biaya produksi merupakan biaya yang menunjang proses jalannya usahatani jeruk siam. Rata - rata biaya tetap usahatani jeruk siam sebesar Rp 1.356.228 per ha/tahun yang terdiri dari biaya penyusutan pembelian cangkul, sprayer mesin, 
sparyer manual, pemotong rumput, sabit, dan pajak tanah. Rata - rata biaya variabel usahatani jeruk siam sebesar Rp 8.645.260 per ha/tahun yang terdiri dari biaya tenaga kerja, baik tenaga kerja dalam keluarga dan luar keluarga, biaya pembelian bibit, pupuk, dan obat-obatan. Untuk lebih terperinci dapat dilihat pada tabel 2.

Tabel 2.

Rata-rata Biaya Variabel dan Biaya Tetap per ha/tahun pada Usahatani Jeruk Siam di Desa Tegalsari, Kecamatan Tegalsari, Kabupaten Banyuwangi, Tahun 2015

\begin{tabular}{|c|c|c|}
\hline No & Uraian & Tahun 2015 \\
\hline \multirow[t]{8}{*}{1} & Biaya tetap & \\
\hline & a. Penyusutan biaya cangkul & 74.103 \\
\hline & b. Penyusutan biaya sprayer mesin & 900.000 \\
\hline & c. Penyusutan biaya sprayer manual & 216.000 \\
\hline & d. Penyusutan biaya pemotong rumput & 90.000 \\
\hline & e. Penyusutan biaya sambit & 33.750 \\
\hline & \multirow[t]{2}{*}{ f. Pajak tanah } & 42.375 \\
\hline & & 1.356 .228 \\
\hline \multirow[t]{12}{*}{2} & Biaya variabel & \\
\hline & \multirow{3}{*}{$\begin{array}{l}\text { a. Biaya tenaga kerja } \\
\text { dalam keluarga } \\
\text { luar keluarga }\end{array}$} & \\
\hline & & 1.055 .411 \\
\hline & & 1.561 .212 \\
\hline & b. Pembelian bibit & - \\
\hline & c. Urea & 1.489 .091 \\
\hline & d. TSP & 1.418 .182 \\
\hline & e. ZA & 2.836 .364 \\
\hline & f. Pupuk daun & 34.545 \\
\hline & g.Obat-obatan & 250.455 \\
\hline & Jumlah & 8.645 .260 \\
\hline & Total biaya & 10.001 .488 \\
\hline
\end{tabular}

Sumber : diolah dari data primer (2015)

\subsection{Penerimaan dan Pendapatan Bersih Usahatani Jeruk Siam}

Pendapatan merupakan selisih antara penerimaan dan biaya usahatani. Menurut Soekartawi (1987), penerimaan adalah jumlah produksi dari komoditas yang dihasilkan oleh petani dikalikan dengan harga yang berlaku saat itu. Biaya usahatani terdiri dari biaya tetap dan biaya variabel. Biaya tetap seperti biaya penyusutan alat pertanian (cangkul, sprayer mesin, sprayer manual, pemotong rambut, dan sabit), pajak tanah dan biaya variabel terdiri biaya tenaga kerja dan biaya sarana produksi. Besarnya penerimaan yang diperoleh oleh responden tahun 2015 di Desa Tegalsari dari usahatani jeruk siam sebesar Rp 35.000.000 per ha/tahun dan pendapatan bersih usahatani jeruk siam adalah penerimaan dikurangi biaya-biaya yang dikeluarkan untuk usahatani jeruk siam yaitu sebesar Rp 24.998.512 per ha/tahun. Data secara rinci mengenai penerimaan, biaya-biaya, dan pendapatan besih responden dalam usahatani jeruk siam pada tabel 3 . 
Tabel 3.

Rata-rata Pendapatan Bersih per ha pada Usahatani Jeruk Siam di Desa Tegalsari, Kecamatan Tegalsari, Kabupaten Banyuwangi,

Tahun 2015

\begin{tabular}{clc}
\hline No & Uraian & Tahun 2015 \\
\hline 1 & Penerimaan & 35.000 .000 \\
2 & Produksi (ha/th) & 7.000 \\
3 & Total biaya tetap & 1.356 .228 \\
4 & Total biaya variabel & 8.645 .260 \\
5 & Total biaya & 10.001 .488 \\
\hline Total pendapatan bersih & 24.998 .512
\end{tabular}

Sumber : diolah dari data primer (2015)

\subsection{Pendapatan Rumah Tangga Petani dari Sektor Non Usahatani}

Menurut Mubyarto (1985), pada dasarnya pendapatan seorang tergantung dari waktu atau jam kerja yang dicurahkan dan tingkat upah per jam kerja yang diterima, antara lain tingkat pendapatan per jam yang diterima, dipengaruhi oleh pendidikan dan keterampilan serta sumber-sumber non tenaga kerja yang dikuasai seperti, tanah, modal, dan teknologi. Makin tinggi pendidikan atau keterampilan serta makin tinggi tingkat pendapatan per waktu yang diterima. Sebaliknya, akan semakin rendah tingkat pendidikannya, keterampilan dan kecilnya sumber-sumber non tenaga kerja. Pada umumnya petani di Desa Tegalsari memperoleh pendapatan dari profesi lain selain petani, seperti pegawai desa, PNS, pedagang, atau buruh bangunan. Hal ini dilakukan untuk mencukupi kebutuhan keluarganya, khususnya sebelum tanaman jeruk siam dapat menghasilkan. Berdasarkan tabel 4 dapat dilihat bahwa sebagian besar petani di Desa Tegalsari juga berprofesi sebagai pedagang, sebesar $87 \%$, dengan pendapatan rata-rata non-usahatani sebesar Rp 8.275.500/tahun.

Tabel 4.

Rata-rata Pendapatan Rumah Tangga Petani dalam Setahun dari Sektor Non Usahatani di Desa Tegalsari, Kecamatan Tegalsari, Kabupaten Banyuwangi Tahun 2015

\begin{tabular}{crccc}
\hline \multirow{2}{*}{ No } & \multirow{2}{*}{ Pekerjaan } & Jumlah (orang) & \multicolumn{2}{c}{ Rata-rata Pendapatan } \\
\cline { 4 - 5 } & & 2 & 11.400 .000 & $\%$ \\
\hline 1 & Pegawai desa & 2 & 21.600000 & 4 \\
2 & Guru & 40 & 8.275 .500 & 87 \\
3 & Pedagang & 2 & 3.000 .000 & 4 \\
4 & Buruh bangunan & 46 & 8.761 .304 & 100 \\
\hline
\end{tabular}

Sumber : diolah dari data primer (2015) 


\subsection{Kontribusi Pendapatan Usahatani Jeruk Siam terhadap Total Pendapatan Rumah Tangga Petani}

Secara garis besar ada dua sumber pendapatan petani, yaitu dari usahatani jeruk siam dan pendapatan dari luar usahatani, seperti pedagang, guru, pegawai desa dan buruh bangunan. Berikut disajikan tabel 5 berupa total pendapatan usahatani dan non usahatani tahun 2015, dimana pendapatan bersih usaha tani merupakan hasil dari panen jeruk pada tahun 2015 .

Tabel 5.

Rata-rata Sumber Pendapatan Petani dalam Setahun di Desa Tegalsari, Kecamatan Tegalsari, Kabupaten Banyuwangi,Tahun 2015.

\begin{tabular}{ccc}
\hline \multirow{2}{*}{ No } & Sumber pendapatan & Rata- rata pendapatan \\
\cline { 3 - 3 } & & $(\mathrm{Rp})$ \\
\hline 1 & Jeruk Siam & 35.000 .000 \\
2 & Non Usahatani & 8.761 .304 \\
\hline & Total & 43.761 .304 \\
\hline
\end{tabular}

Sumber : diolah dari data primer (2015)

Berdasarkan tabel 5, diketahui besar total rata-rata pendapatan rumah tangga petani pada Kelompok Tani Komojoyo jeruk siam,Desa Tegalsari,Kabupaten Banyuwangi adalah sebesar Rp 43.761.304. Total rata-rata pendapatan petani tahun 2015 selama setahun menunjukkan bahwa pendapatan yang didapat dari usahatani jeruk siam sebesar Rp 35.000.000, sedangkan pendapatan non usahatani sebesar Rp 8.761.304. Berdasarkan tabel tersebut menunjukkan bahwa pendapatan terbesar diperoleh dari sektor pertanian yakni usahatani jeruk siam, dan terbesar kedua diperoleh dari sektor non usahatani.

Tabel 6.

Hasil Kontribusi Pendapatan Usahatani Jeruk Siam terhadap Total Pendapatan Rumah Tangga Petani di Desa Tegalsari, Kecamatan Tegalsari, Kabupaten Banyuwangi, Tahun 2015.

\begin{tabular}{ccclccc}
\hline \multirow{2}{*}{ Kelas } & \multicolumn{2}{c}{ Batas kelas $(\boldsymbol{\%})$} & & \multirow{2}{*}{ Kriteria } & Frekuensi & \multirow{2}{*}{$(\boldsymbol{\%})$} \\
\cline { 2 - 3 } & Bawah & Atas & & 9 & 18,86 \\
\hline 1 & 0 & 20 & Sangat rendah & - & - \\
2 & 20 & 40 & Rendah & 25 & 56,67 \\
3 & 40 & 60 & Sedang & 12 & 75,43 \\
4 & 60 & 80 & Tinggi & - & - \\
5 & 80 & 100 & Sangat tinggi & & \\
\hline
\end{tabular}

Sumber : diolah dari data primer (2015)

Berdasarkan tabel 6, menggambarkan hasil kontribusi pendapatan usahatani jeruk siam terhadap total pendapatan petani dalam bentuk kriteria dari sangat rendah hingga sangat tinggi. Terdapat frekuensi yang bertujuan untuk mengetahui seberapa banyak jumlah yang menduduki kriteria tersebut dan berapa persentase yang diperoleh dari 
setiap criteria. Hasil kontribusi pendapatan usahatani jeruk siam terhadap total pendapatan rumah tangga petani diperoleh dari rumus kontribusi, yakni pendapatan usahatani jeruk siam dibagi jumlah pendapatan usahatani jeruk siam dan pendapatan non usahatani, kemudian dikalikan $100 \%$. Hasil yang didapatkan dari setiap responden kemudian dicari untuk menentukan frekuensi sesuai kriteria yang telah ditentukan seperti tabel 6.

Berdasarkan tabel 6, diperoleh frekuensi hasil kontribusi pendapatan usahatani jeruk siam terhadap total pendapatan rumah tangga petani, sejumlah sembilan orang dengan persentase 18,86\% dengan kategori sangat rendah. Frekuensi sejumlah 25 orang dengan persentase 56,67\% dengan kriteria sedang, kemudian frekuensi sejumlah 12 orang dengan persentase $75,43 \%$ dengan kategori tinggi.

\subsection{Kendala-kendala yang dihadapi Petani dalam Usahatani Jeruk Siam}

Hasil penelitian pada Kelompok Tani Komojoyo, Desa Tegalsari, Kecamatan Tegalsari, Kabupaten Banyuwangi, masih dijumpai beberapa permasalahan. Permasalahan tersebut menyebabkan belum optimalnya produktivitas tanaman dan pendapatan petani.

Permasalahan teknis yang dihadapi oleh petani antara lain, hama penyakit yang menyerang tanaman jeruk siam. Hama penyakit tersebut ialah kutu daun (Aphids $s p$ ) yang menyerang tunas dan daun muda dengan cara menghisap cairan tanaman sehingga helaian daun menggulung. Koloni kutu ini berwarna hitam, cokelat atau hijau tergantung spesiesnya, disamping itu, kutu juga mengeluarkan toksin melalui salivanya sehingga timbul gejala kerdil, deformasi dan terbentuk puru pada helaian daun.

Hal lain yang dibutuhkan para petani adalah optimalisasi bimbingan yang dilakukan oleh para penyuluh pertanian. Para petani membutuhkan informasi terbaru dari pihak terkait agar bisa meningkatkan pemeliharaan tanaman dengan pengetahuan terbaru dari pihak penyuluh pertanian. Adanya tambahan informasi terbaru seperti teknologi pembuatan pupuk organik, cara menghasilkan produksi jeruk siam yang melimpah tanpa menggunakan bahan kimia dan lain-lain. Jika terdapat informasi terbaru seputar pertanian maka semakin meningkat tingkat pengetahuan dalam mengelolah tanaman jeruk. Hal tersebut tentu berdampak pada peningkatan hasil panen yang didapat. Kendala selanjutnya ialah penjualan hasil panen. Petani masih tergantung pada para tengkulak. Hal tersebut cenderung menyebabkan hasil pertanian dibeli secara borongan sehingga petani tidak bisa menetapkan harga.

\section{Kesimpulan dan Saran}

\subsection{Kesimpulan}

Berdasarkan hasil dan pembahasan pada bab sebelumnya, maka dapat diambil simpulan sebagai berikut.

1. Rata-rata sumber pendapatan petani dalam pada Kelompok Tani Komojoyo di Desa Tegalsari, Kecamatan Tegalsari, Kabupaten Banyuwangi sebesar Rp 35.000.000 sedangkan rata-rata sumber pendapatan non usahatani sebesar Rp 
8.761.304. Dapat disimpulkan bahwa pendapatan usahatani jeruk siam lebih besar dibandingkan pendapatan non usahatani. Jika kontribusi tersebut dihitung pada setiap responden maka frekuensi kontribusi pendapatan usahatani jeruk siam terhadap rumah tangga petani sebanyak 25 orang sebesar $56,57 \%$ dengan kategori sedang.

2. Terdapat kendala - kendala yang dihadapi para petani di Desa Tegalsari, Kecamatan Tegalsari, Kabupaten Banyuwangi yakni terdapat hama penyakit kutu daun yang menyerang tanaman jeruk, kurang optimal penyampaian informasi terbaru dan bimbingan ke petani mengenai perawatan dan pasca panen jeruk, dan ketergantungan kepada tengkulak menyebabkan hasil jeruk dibeli secara borongan sehingga petani tidak bisa menetapkan harga, maka keuntungan petani berkurang.

\subsection{Saran}

Dari uraian pembahasan dan simpulan di atas, adapun saran yang dapat penulis berikan sebagai berikut.

1. Petani disarankan dapat mempertahankan usahatani jeruk siam untuk menambah pendapatan (income) per kapita/tahun.

2. Dibutuhkan konsisten dan komitmen antar petani agar dapat menghasilkan produksi jeruk siam yang berkualitas yang bisa memenuhi kebutuhan jeruk siam di Kabupaten Banyuwangi maupun luar kota.

3. Dibutuhkan penyuluhan dan pembinaan secara teknis tentang penanggulangan hama penyakit, informasi terbaru terkait teknologi pertanian agar dapat mengoptimalkan produksi jeruk siam sebagai salah satu sumber pendapatan di Desa Tegalsari.

4. Perlu dibentuknya koperasi atau STA (Sub Terminal Agribisnis), agar bisa mengolah hasil dan harga panen jeruk siam dengan baik

\section{Ucapan Terimakasih}

Penelitian ini tidak mungkin terlaksana tanpa adanya bantuan berbagai pihak, maka dari itu pada kesempatan ini penulis menyampaikan rasa terimakasih kepada Kelompok Tani Komojoyo, Desa Tegalsari, Kecamatan Tegalsari, Kabupaten Banyuwangi. Tidak lupa juga kepada para pembimbing yang telah memberikan bimbingan dengan sabar dan teliti kepada penulis dari awal sampai akhir hingga e-jurnal ini selesai, serta seluruh pihak yang membantu kelancaran penelitian ini.

\section{Daftar Pustaka}

Departemen Pertanian. 2012. Budidaya Tanaman Jeruk

Dinas Pertanian, Kehutanan, dan Pekerbunan Kabupaten Banyuwangi. 2012. Banyuwangi dalam Angka Tahun 2012.

Effendi, Sofyan dan Chris Manning, 1989. Prinsip - prinsip Analisa Data Penyunting : Masri Singaribun dan Sofyan Effendi. Metode Penelitian Survei. LP3ES. Jakarta. 
Krisnandhi, S. 2009. Menggerakkan dan Membangun Pertanian. C.V. Yasaguna. Jakarta.

Mantra, Ida Bagoes dan Kasto. 1989. Penentuan Sampel. Penyunting Masri Singarimbun dan Sofyan Effendi. Metode Penelitian Survei. LP3ES. Jakarta.

Mubyarto, 1985. Peluang Kerja dan Kesempatan Berusaha di Pedesaan. BPEF, Yogyakarta.

Sajogyo.1990. Pembangunan Pertanian dan Pedesaan dalam Rangka Industrialisasi Bunga rampai: Industrialisasi Pedesaan, Tambunan. Sekindo Eka Jaya. Jakarta

Sarwono, B. 1986. Jeruk dan Kerabatnya. Jakarta : Penerbit Swadaya.

Soekartawi. 1986. Ilmu Usahatani dan Penelitian untuk Pengembangan Pertanian Kecil. Universitas Indonesia Press. Jakarta.

Soekartawi. 1995:a. Analisis Usahatani. Universitas Indonesia. Jakarta 